\title{
Future Expectation of the Photovoltaics Role in Compensating Energy Demand
}

\author{
Z. ER* AND I.B. TURNA \\ Istanbul Technical University, Faculty of Science and Letters, Physics Engineering Department (13b), \\ 34469 Maslak-İstanbul, Turkey
}

\begin{abstract}
Photovoltaics (PV) is becoming a mainstream electricity provider and the need for PV cells will spike compared to current demand. Solar power is based on obtaining electricity from solar radiation by using either photovoltaic cells or concentrated solar power (CSP). Both systems have different requirement to the area and advantages. However, there are several common disadvantages, which are related to the initial cost and regulatory issues that prevent investors from starting up such projects. Based on these premises the utilization of the solar power was examined in this study by highlighting the world's sustainable energy potential and investment statistics. Therefore research analysis related to the solar energy potential is presented as well. Although, the sustainable energy is the future of the world and requires slightly less amount of expense after installation, compared to conventional energy sources, the installation costs are the predominant factor of the utilization of the sustainable energy technologies. Furthermore, this study makes an overview of the world's solar power capacity today and makes prediction for the future. This study presents comprehensive market data together with forecasts for the short-run, while the role of $\mathrm{PV}$ is discussed considering the demand of energy.
\end{abstract}

DOI: 10.12693/APhysPolA.129.865

PACS/topics: 89.20.Bb

\section{Introduction}

The technology is progressing steadily and the dependence on the electric energy becomes more crucial. Thus the investigation of electric energy supply is more challenging than ever, which evokes the demand for new energy sources besides the coal, oil and nuclear power.

The aforesaid issue has been underlined in the World Energy Council with the UN Framework Convention on Climate Change, which invites all parties in various industries to start investment in renewable energy sources [1]. Solar power is one of the most considerable sustainable energy sources and has a paramount historical background, started with conversion of sun light into electricity in 19th century and then after observations on photovoltaic (PV) effect by Alexandre Edmond Becquerel, the electric energy production has been advancing and there is still a greater concern on the development of new technologies which would enable more efficient approaches [2].

Subsequently PV is the most promising solar technology in this century, which converts solar radiation to electric energy, while the demand on electricity is growing, together with the increase in population and the needs of the industry, due to supply of services to the society. Furthermore, economic, governmental and environmental priorities also influence the development of the PV systems.

Two major drivers in the governmental aspect are the policies and subsidies. Policies should not be restricted

*corresponding author; e-mail: erzuh@itu.edu.tr within the framework of regional issues, as the energy concern is worldwide and the communities, including involvement of nongovernmental organizations are casting those policies. Governments and in global sense state policies are expected to bolster not only the investors, universities and communities that could improve PV technologies, but also the new research fields in sustainable energy technology.

This study highlights the world's sustainable energy potential and investment statistics based on various states in conjunction with the planned energy demand. Thus the pros and cons of the investment are also briefly pointed out within the perspective of sustainable energy, while highlighting the solar power.

\section{World's sustainable energy potential}

Sustainable energy has gained more popularity among both investors and government officials during last three decades. In 1990, the most common sustainable energy sources were coined as hydro power and biomass [1]. Then, when researches have demonstrated suitable ground for their efficient application, solar energy, wind energy and geothermal energy have become indispensable alternatives in the gamut of sustainable energy sources.

The statistics of Renewable Energy Policy Network for the 21st Century, obviously underlines the rise in renewable electricity production since the year 2000 [3]. Thereby it was observed that energy production capacity by biomass energy and geothermal energy remained reasonably steady while there was an acceleration in production of wind energy infrastructure until 2008 and then electricity production capacity by wind energy went upwards rapidly. Hydropower which remains as renewable 
energy since 1993 has increased gradually reaching a peak in 2003 and then continued to fluctuate, however its behavior can be interpreted as the general upwards trend. On the other hand, solar power, which includes PV and concentrated solar power, continued to increase not leveling off by the end of 2009 and rose sharply without dou- bling the 2009 peak. The measured figures on electric energy production had reached $748 \mathrm{GW}$ in the year 2000 and have increased up to $1560 \mathrm{GW}$ in 2013 due to the increase of the installed capacity by $108 \%$. Figure 1 shows the renewable energy indicators in 2013 .

\begin{tabular}{|c|c|c|c|c|}
\hline & & START 2004: & END 2012 & END 2013 \\
\hline \multicolumn{5}{|l|}{ INVESTMENT } \\
\hline $\begin{array}{l}\text { New investment (annual) } \\
\text { in renewable power and fueis }{ }^{2}\end{array}$ & billion USD & 39.5 & 249.5 & $214.4(249.4)$ \\
\hline \multicolumn{5}{|l|}{ POWER } \\
\hline $\begin{array}{l}\text { Renewable power capacity } \\
\text { (total, not including hydro) }\end{array}$ & GW & 85 & 480 & 560 \\
\hline $\begin{array}{l}\text { Renewable power capacity } \\
\text { (total, including hydro) }\end{array}$ & GW & 800 & 1,440 & 1,560 \\
\hline$\approx$ Hydropower capacity (total)? & GW & 715 & 960 & 1,000 \\
\hline D. Bio-power capacity & GW & $<36$ & 83 & 88 \\
\hline A Bio-power generation & TWh & 227 & 350 & 405 \\
\hline [0] Geothermal power capacity & GW & 8.9 & 11.5 & 12 \\
\hline a Solar PV capacity (total) & GW & 2.6 & 100 & 139 \\
\hline 9 Concentrating solar thermal power (total) & GW & 0.4 & 2.5 & 3.4 \\
\hline W Wind power capacity (totai) & GW & 48 & 283 & 318 \\
\hline \multicolumn{5}{|l|}{ HEAT } \\
\hline [0. Solar hot water capacity (total) $4^{4}$ & $\mathrm{GW}_{\text {th }}$ & 98 & 282 & 326 \\
\hline \multicolumn{5}{|l|}{ TRANSPORT } \\
\hline Q Ethanol production (annual) & biltion litres & 28.5 & 82.6 & 87.2 \\
\hline Diodiesel production (annual) & billion litres & 2.4 & 23.6 & 26.3 \\
\hline \multicolumn{5}{|l|}{ POLICIES } \\
\hline Countries with policy targets & $\#$ & 48 & 138 & 144 \\
\hline $\begin{array}{l}\text { Feed-in } \\
\text { Number of states/ provinces/ countries }\end{array}$ & $\#$ & 34 & 97 & 98 \\
\hline $\begin{array}{l}\text { RPS / quota policies } \\
\text { Number of states/ provinces/ countries }\end{array}$ & $\#$ & 11 & 79 & 79 \\
\hline $\begin{array}{l}\text { Tendering } \\
\text { Number of states/ provinces/ countries }\end{array}$ & $\#$ & 8 & 45 & 55 \\
\hline $\begin{array}{l}\text { Heat obligations / mandates } \\
\text { Number of countries }\end{array}$ & $\#$ & $n / a$ & 19 & 19 \\
\hline $\begin{array}{l}\text { Biofuel obligations/ mandates } 5 \\
\text { Number of countries }\end{array}$ & $\#$ & 10 & 52 & 63 \\
\hline
\end{tabular}

Fig. 1. Renewable energy indicators 2013 [3].

Evaluation of sustainable energy according to countries indicates that there are several countries which are always remaining at the top of the list. In Europe region in accordance with the data promulgated by The European Wind Energy Association, the total installed capacity during 2013 was 11159 MW. Germany was the leading country in Europe with 29 percent of total capacity, followed by United Kingdom with 1883 MW [4]. Figure 2 illustrates EU Members State Market Shares For New Capacity Installed During 2013 in MW. In the scale of the world, Germany was in the third place of the list, whereas China was the leader of the world in wind energy, followed by United States. However, United States take the lead at the geothermal energy installed capacity in 2015 with 5090 GW, which is followed by Asia Pacific countries with $4810 \mathrm{GW}$, such as Philippines (the second) and followed by Indonesia and Mexico. Likewise, China and United States are the greatest producers of biomass and hydropower energy [5]. Figure 3 shows installed capacity in 2015 worldwide (12600 GW).

All in all, European Photovoltaic Industry Association has underlined in its Global Market Outlook report that 


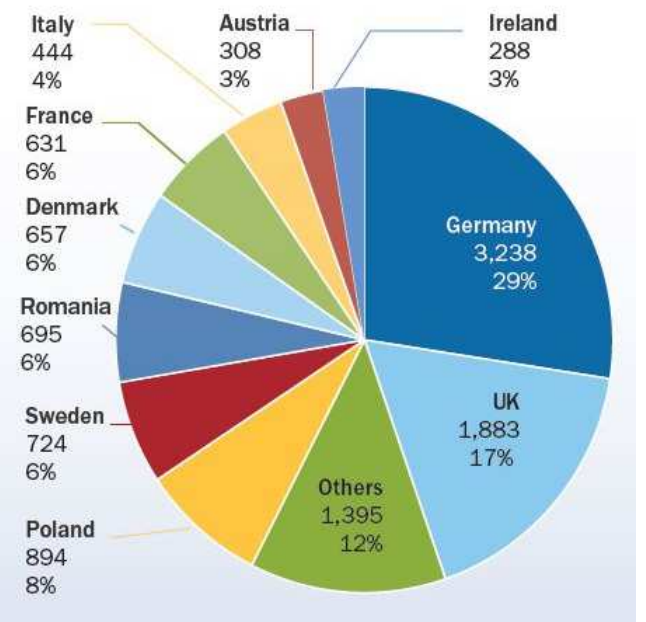

Fig. 2. EU members state market shares for new capacity installed during 2013 in MW, with total of 11159 MW [4].

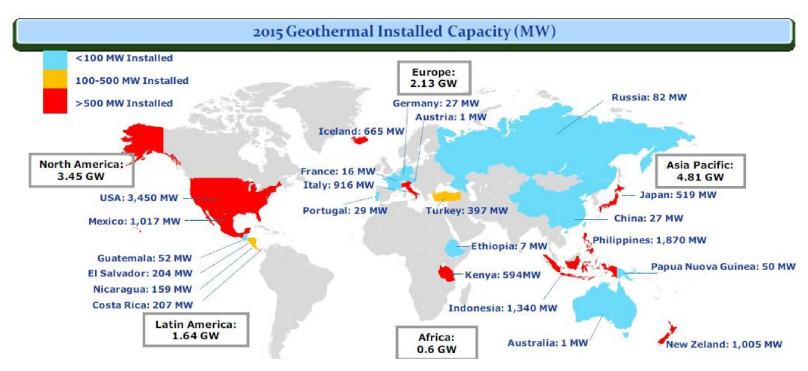

Fig. 3. Installed capacity in 2015 worldwide (12600 GW) [5].

the global PV cumulative installed capacity at the very first part of the year 2000 was not leveling, but rising, and has reached $138833 \mathrm{MW}$ at the end of 2013 [6]. Subsequently it is obvious that sustainable energy installed capacity increases with time and is expected to increase in the short-run while the environmental concern and

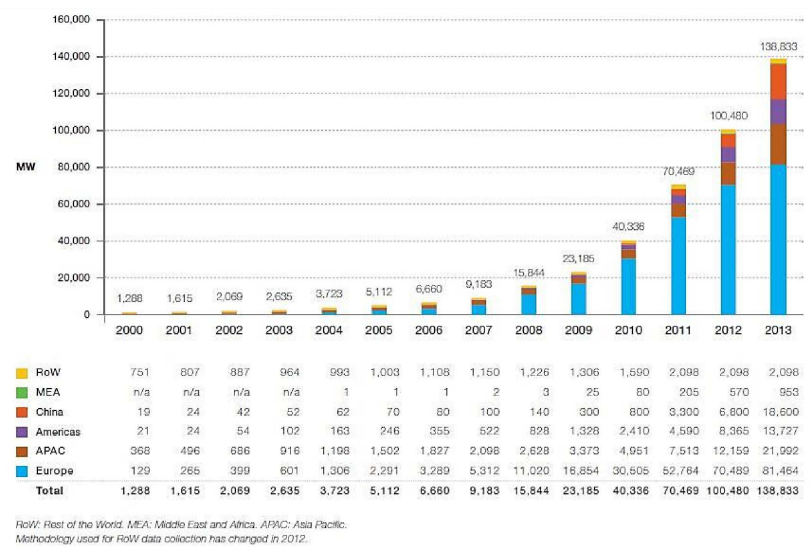

Fig. 4. Evolution of global PV cumulative installed capacity 2000-2013 [6]. pressure on pollution prevention efforts are persistently threatening the future of the planet. Figure 4 shows the evolution of global PV cumulative installed capacity $2000-2013$ [6].

\section{World's solar potential}

Solar power has a capacity and potential to significantly cover the energy demand by providing efficient technology and permanent energy source, if properly managed and supported by authorities. The aforementioned technologies gather the small amount of the radiation energy emitted by Sun and intercepted by the Earth. Inherently radiation could be converted to heat or electricity.

In this study, the production of electric energy from solar radiation was mainly considered based on two systems which are the PVs and concentrated solar power (CSP). The main difference between those two developed technologies is the existence of a turbine in CSP installation. PV systems use solar cells to transform solar radiation to electricity directly while CSP systems make the same transformation using a turbine, after solar thermal energy was used to produce the steam. The PV systems have a major percentage of world cumulative solar power capacity compared with the application of CSP systems. The global annual capacity growth rate of renewable electricity between 2000 and 2013 was $23.3 \%$ for CSP while it was $46.8 \%$ for PV systems.

The installed PV capacity in Europe region has witnessed a sharp rise between 2007 and 2008 [1], which was followed by rapid increase until 2013. It is recognized that there are still wide application possibilities of PVs in Asia Pacific region, predominantly in China. Finally, the US had significant improvement in capacity on PV technology together with the existing installed capacity.

Consequently it is worth to underline that the utilization of both PVs and CSPs technologies is permanent as long as the Sun exists.

\section{Conclusions and discussion}

The sustainable energy is the precise and unique solution for compensating the existing energy demand mentioned in the previous sections, which needs investment to expand its field of application on this planet. The PV market has grown despite the constraints confronted by sectors such as the impact of economic crisis and obstacles of implementation of policies.

On the contrary, the solar investments were increasing gradually having a peak in 2011 with 157.8 billion US dollars. Then the investment has declined having 113.7 billion US dollars by the end of 2013, according to the data, published by Frankfurt School of Finance and Management [7]. The fluctuation was not witnessed solely in PV sector but also in the overall global trend in renewable investment, which had a peak and then went downwards. When the total new investments are evaluated on regional basis, they illustrate that the changes 
in figures are similar, as expected. The total sustainable energy investments have declined in 2013 by $12 \%$, compared with the year 2012 and by $23 \%$, compared with the year 2011 in the worldwide scale [8].

The technological costs may be referred to the economical aspect of the sustainable energy, where the pinpoint of the decline in sustainable energy investments, mainly in the developed nations, could be related to uncertainties in incentive policies especially in Europe and United States. Therefore the other reason that causes the decrease of the investments in Europe might be China, because China prefers to invest in sustainable energy projects more than it needs.

It is believed that as long as scientific researches and developments continues, the technology will be improved with the time. Energy resources and efficient technologies will be the indispensable solution for the energy demand under the circumstances of appropriate strategies. Sustainable energy potential depends on environmental conditions. Further, the governmental, technological and scientific contribution have the major role for the energy supply and its application in every branch of the industry. Therefore, less constrains on the aforesaid mainstreams will eventually cause the enlarging of the utilization of alternative resources.

\section{References}

[1] World Energy Council, World Energy Resources: 2013 Survey, 2013, p. 330.

[2] L.M. Fraas, Low-Cost Solar Electric Power, Ch. 1, Springer, USA 2014.

[3] Renewable Energy Policy Network for the $21^{\text {st }}$ Century, Renewables 2014 Global Status Report, 2014.

[4] The European Wind Energy Association, Wind in Power: 2013 European Statistics, 2014.

[5] R. Bertani, Geotherm. 60, 31 (2016).

[6] European Photovoltaic Industry Association, Global Market Outlook for Photovoltaics 2014-2018, 2014.

[7] Frankfurt: Frankfurt School - UNEP Collaborating Centre for Climate \& Sustainable Energy Finance, Global Trends in Renewable Energy Investment 2014, 2014.

[8] Bloomberg New Energy Finance, Global Trends in Clean Energy Investment Q4 2013, 2014. 